Notre Dame Law School

NDLScholarship

Journal Articles

Publications

6-24-2015

\title{
How to Kill a Zombie: Strategies for Dealing with the Aftermath of the Foreclosure Crisis
}

Judith L. Fox

Notre Dame Law School, judith.l.fox.30@nd.edu

Follow this and additional works at: https://scholarship.law.nd.edu/law_faculty_scholarship

Part of the Property Law and Real Estate Commons

\section{Recommended Citation}

Judith L. Fox, How to Kill a Zombie: Strategies for Dealing with the Aftermath of the Foreclosure Crisis, 1519 Notre Dame Legal Studies Paper.

Available at: https://scholarship.law.nd.edu/law_faculty_scholarship/1208

This Article is brought to you for free and open access by the Publications at NDLScholarship. It has been accepted for inclusion in Journal Articles by an authorized administrator of NDLScholarship. For more information, please contact lawdr@nd.edu. 


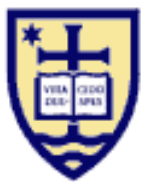

U N I V E R S I T Y O F NOTRE DAME

THE LAW SCHOOL

\title{
HOW TO KILL A ZOMBIE: STRATEGIES FOR DEALING WITH \\ THE AFTERMATH OF THE FORECLOSURE CRISIS
}

\author{
Judith Fox \\ Clinical Professor of Law \\ Notre Dame Law School
}

Notre Dame Law School Legal Studies Research Paper No. 1519

A complete list of Research Papers in this Series can be found at: http://www.ssrn.com/link/notre-dame-legal-studies.html 
HOW TO KILL A ZOMBIE:

STRATEGIES FOR DEALING WITH THE AFTERMATH OF THE FORECLOSURE CRISIS

(Draft)

Judith Fox

\begin{abstract}
The foreclosure crisis which began in 2008 is old news; or is it? A lot of attention has been paid to the plight of homeowners struggling to save their homes from foreclosure. Legislative and regulatory changes have made it easier for homeowners to navigate the loss mitigation process. A significant number of people, however, did not try to save their homes. In fact, some actively tried unsuccessfully to give the homes back to their lender. These abandoned homes and abandoned foreclosures have become zombie mortgages. This is the legacy of this crisis.

The existence of these homes is well documented and this paper does not seek to prove the problem. Instead, it analyzes some solutions. How can homeowners re-gain control of these homes in order to solve the urban plight problem the foreclosure crisis left in its wake? Current law does not anticipate a bank not seeking foreclosure. Should it?

Courts are just beginning to grapple with the situation. No consistent patterns have emerged to deal with the issues. The mortgage industry has argued throughout this crisis that delays in judicial foreclosure are one of the causes of this phenomena. The data has failed to support this hypothesis. On the contrary, this paper argues that the industry used every legal maneuver possible to exacerbate the problem. Lenders have been allowed to enjoy the benefits of the mortgage, while avoiding the burdens. Changes in policy and perception are needed if we are ever to move pass the crisis.
\end{abstract}


HOW TO KILL A ZOMBIE:

\section{STRATEGIES FOR DEALING WITH THE AFTERMATH OF THE FORECLOSURE CRISIS Judith Fox ${ }^{1}$}

Zombies are popular in America today. The Walking Dead, a show about an apocalyptic world full of zombies, is cable’s most popular television show. ${ }^{2}$ Academics and policymakers have embraced the terminology in describing the numerous abandoned foreclosures in America. ${ }^{3}$ In February, 2015, RealtyTrac reported that one quarter of all foreclosures in American could now be considered "zombie foreclosures." ${ }^{4}$ The problem is so widespread that one Cleveland Municipal Judge created a webpage to explain both what a zombie mortgage is and how a homeowner can determine if he or she is has become its victim. ${ }^{5}$ The chart below documents the prevalence of zombie loans:

\footnotetext{
${ }^{1}$ Clinical Professor, Notre Dame Law School

${ }^{2}$ Allen St. John, The Most Watched Hour Ever: Why 'The Walking Dead' Season Finale Will Break A Ratings Record, FORBES (March 20, 2014), http://www.forbes.com/sites/allenstjohn/2014/03/30/the-most-watched-hourever-why-the-walking-dead-season-finale-will-break-a-ratings-record/.

${ }^{3}$ Michael S. Waldron, CFPB Considering Action on Zombie Foreclosures, 68 CONSUMER FIN. L. Q. REP. 49 (2014); David P. Weber, Zombie Mortgages, Real Estate, and the Fallout of Survivors, 46 N.M.L. REV. 37 (2014); Andrea Clark, comment, Amidst the Walking Dead: Judicial and NonJudicial Approaches for Eradicating Zombie Mortgages, 65 EMORY LAW J. (forthcoming 2015), http://papers.ssrn.com/sol3/papers.cfm?abstract id=2583267; Michelle Conlin, Special Report: The Latest foreclosure horror: the zombie title, REUTERS (JAN. 10, 2013, 1:58 pm), http://www.reuters.com.article/2013/01/10/us-usa-foreclosures-zombies-IDusbre9090g920130110;;

${ }^{4}$ One in Four US Foreclosures are “Zombies” Vacated by Homeowner, Not Yet Repossessed By Foreclosing Lender, (February 5, 2010), http://www.realtytrac.com/news/foreclosure-trends/zombie-foreclosures-q1-2015./. [Hereinafter RealtyTrac\}.

${ }^{5}$ Raymond L. Pianka, Zombie Mortgages and Zombie Titles, Clev. Mun. CT. Hous. Div., http://clevelandhousingcourt.org/zombies.html.
} 


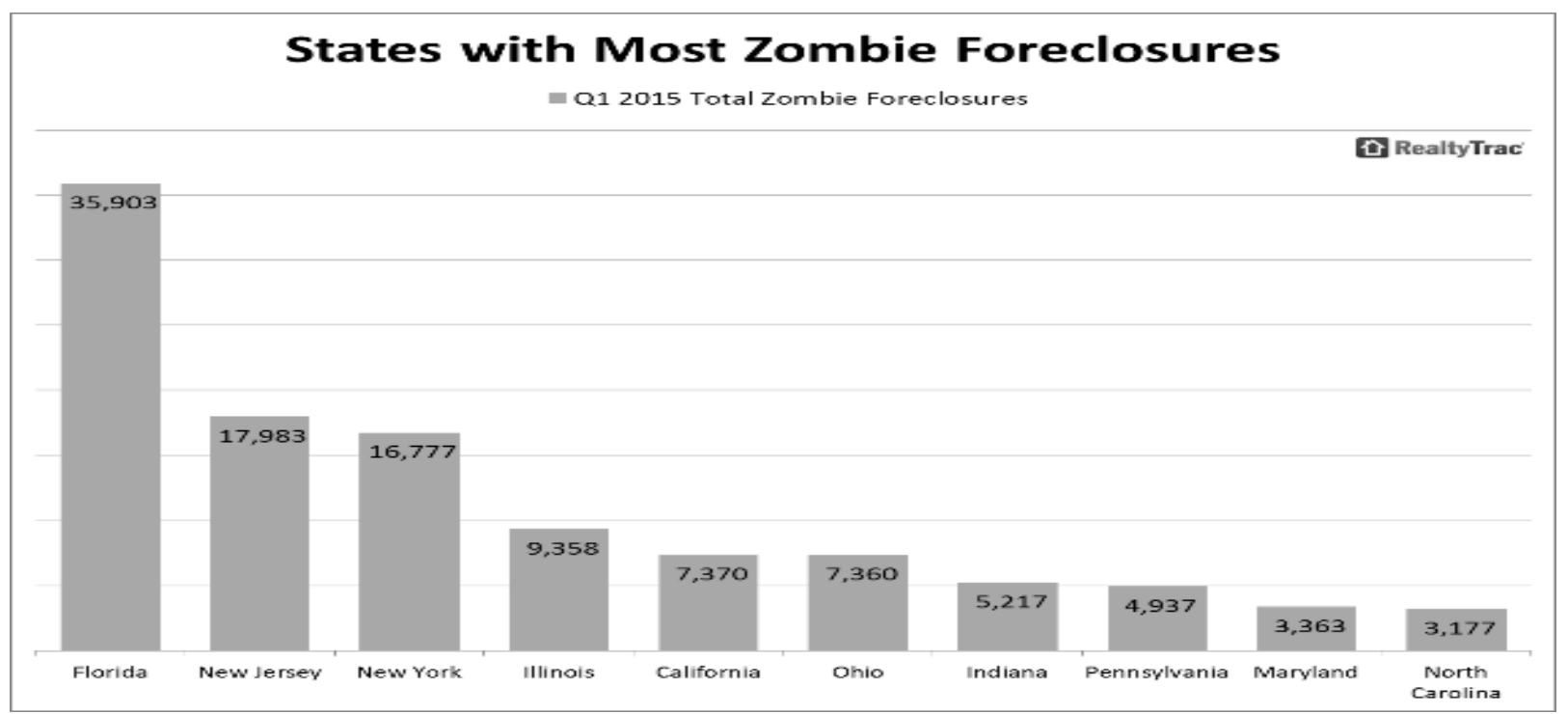

Chart I: RealtyTrac Q1 2015 Total Zombie Foreclosures ${ }^{6}$

RealtyTrac's definition of a zombie foreclosure is narrow: any home "actively in the foreclosure process" that has been "vacated by the homeowner prior to the bank repossessing the property." 7 This paper adds to that definition those mortgages that were once, but are no longer "actively in the foreclosure process whether or not they are occupied.”

These are the true zombie mortgages. Like the characters of popular culture, a true zombie mortgage is a creature you thought had died only to see it reborn to hunt and haunt you. Zombie mortgages have contributed to the growing problem of abandoned properties, especially in urban centers across America. ${ }^{8}$ You can go to Youtube and watch a video describing 100 ways to kill a human zombie, ${ }^{9}$ but we have yet to perfect a technique for laying a zombie mortgage to rest. This article attempts to do just that. Most of the existing scholarship on this

\footnotetext{
${ }^{6}$ Id.

${ }^{7}$ RealtyTrac, supra note 4.

${ }^{8}$ Id.

${ }^{9} 10$ Ways to Kill a Zombie,https://www.youtube.com/watch?v=55CGhH8KglA.
} 
issue focuses on strategies for municipalities and governments. ${ }^{10}$ Unfortunately, while a few of these proposed solutions have proven successful, ${ }^{11}$ most have been met with severe opposition. ${ }^{12}$ What is left? This paper argues that the focus of the solution needs to shift from the macro to the micro. In essence, this disease has been separated from the patient, the homeowner. Only when we cure the homeowner's ills will we begin to kill the virus that has caused the spread of the zombie mortgage.

Part I briefly defines and differentiates between stalled and abandoned foreclosures and zombie loans. Part II discusses how a homeowner might successfully return a property to the lender through bankruptcy when a lender refuses to foreclose. The options are limited, as the reader will soon discover. Part III explores some of the possible legal theories left to homeowners through the lens of Kathleen's case, a particular zombie foreclosure. Communities need to join forces with homeowners to improve how the law deals with zombie mortgages. So long as it remains profitable to do so, the lending industry will continue to abandon foreclosures and create zombie mortgages. Zombie mortgages will only die when it is no longer profitable to abandon the foreclosure. The courts can assist by creating negative incentives. If a creditor's

\footnotetext{
${ }^{10}$ See, i.e. Creola Johnson, Fight Blight: Cities Sue to Hold Lenders Responsible for the Rise in Foreclosures and Abandoned Properties, 2008 UTAH L. REV. 1169 ; James J. Kelly Jr., A continuum in remedies: reconnecting Vacant Homes to the Market, 33 ST. LouIs U. PuB. L. REV. 109 (2013).

${ }^{11}$ Luke Broadwater, Wells Fargo agrees to pay \$175 M settlement in pricing discrimination suite, BALTIMORE Sun, (June 12, 2012), http://articles.baltimoresun.com/2012-07-12/news/bs-md-ci-wells-fargo-20120712_1_mike-heidwells-fargo-home-mortgage-subprime-mortgages.

${ }^{12}$ Fed. Housing Financing Agency v. City of Chicago, 962 F. Supp. 2d. 1044 (N. Dist. Ill.,2013) (a successful challenge to prevent the city of Chicago from enacting ordinance that would require to pay $\$ 500$ for each property it abandons); Sam Forgione, Investors Withdraw Appeals Against California Eminent Domain Plan, ReuTERS ( May 16, 2014), available at http://www.reuters.com/article/2014/05/17/us-mortgages-investing-eminentdomainidUSBREA4G00A2014516

${ }^{12}$ Jennifer Medina, California County Weight Drastic Plan to Aid Homeowners, N.Y. TIMEs (July 14, 2012), http://www.nytimes.com/2012/07/15/us/a-county-considers-rescue-of-underwater-homes.pdf.; Joe Tyrrell, NJ Town Turns to Eminent Domain to Clean up Blight of Foreclosed Houses, NJSPOTLIGHT , (November 20, 2013), http://www.njspotlight.com/stories/13/11/19/nj-town-turns-to-eminent-domain-to-clean-up-blight-of-foreclosedhouses/?p=all.

${ }_{12}$ Shaila Dewan, More Cities Consider Using Eminent Domain to Halt Foreclosures, N.Y. TIMES,(November 15, 2013), http://www.nytimes.com/2012/07/15/us/a-county-considers-rescue-of-underwater-homes.pdf
} 
acts manifest intent to abandon their obligations under a mortgage, courts should consider it abandoned, and eliminate the benefits as well. Only then will creditors be motivated to act on their rights in a timely fashion, least they lose them. While a recovering housing market may assist in moving the current batch of abandoned foreclosures back on the market, it comes too late for most of these homes. They are no longer marketable. It is likely we will not have to wait long before the next housing crisis. ${ }^{13}$ We are best advised to create some solutions for this crisis before we are in the midst of the next.

\section{I. $\quad$ HOW TO IDENTIFY A ZOMBIE}

The terms “abandoned foreclosure” and “zombie mortgage” have been used interchangeably in the literature. In this paper the two are distinguished because they present different challenges. Not all abandoned foreclosures result in an abandoned property. In a 2010 study of abandoned foreclosures, the governmental accounting office found that people tend to abandon their property if the foreclosure has been initiated and the bank fails to follow-through and not if the foreclosure is never initiated, despite a default by the borrower. ${ }^{14}$ The logical explanation for this is that people abandon their property because they believe it has been lost in foreclosure. In 2012 the Board of Governors of the Federal Reserve System responded to the by issuing guidance to lenders regarding when and how they should discontinue a foreclosure. ${ }^{15}$

\footnotetext{
${ }^{13}$ Steve H. Hanke, The great 19-Year Real Estate Cycle, CATO INST. http://www.cato.org/publications/commentary/great-18year-real-estate-cycle (predicting a housing bubble every eighteen years).

${ }^{14}$ U.S. Gov'T Accountability Office, GaO-11-93, Mortgage Servicer Action Could Help Reduce The FREQUENCY AND IMPACT OF ABANDONED FOREClOSURES 17 (2010). See also Katie Buitrago, Deciphering Blight: Vacant Building Data Collection in Chicago Six County Region, WoODSTOCK INST. 3 (June 2013), http://www.woodstockinstorg/sites/default/files/attachments/dechipheringblight_buitrago_june 2013.pdf (finding abandonment more likely when foreclosure is initiated, but not pursued).

${ }^{15}$ Supervision ANd Regulation LetTERS, BoARd Of Governors Of THE FEDERAL RESERve System, Guidance on a Lender's Decision to Discontinue Foreclosure Proceedings, July 11, 2012, http://www.federalreserve.gov/bankinforeg/srletters/sr1211.pdf.
} 
Specifically, the guidance encourages lenders to notify homeowners and communities when they abandoned a foreclosure in order to avoid the incidents of abandoned properties. Compliance with that guidance is spotty at best. The Consumer Financial Protection Bureau found it “'extremely common' for servicers to charge off low-balance loans and not notify borrows or municipalities if they did not complete the foreclosure." ${ }^{16}$ Currently, there is no law or regulation preventing a lender from initiating and then abandoning a foreclosure.

In fact, the existing guidance available to lenders may be complicating the situation. For example, the Truth in Lending Act requires servicers to send monthly statements to any borrower who has a delinquent mortgage debt. ${ }^{17}$ Lori Maggiano, an official with the CFPB, opined that this provision may be pushing "servicers to release the borrower from liability for the debt," without expressing the clear effects on the corresponding lien. ${ }^{18}$ Does this mean that the homeowner's debt is simply charged-off or is it truly forgiven? ${ }^{19}$ The Office of the Comptroller of the Currency instructs mortgage lenders to give no indication "to the borrower that the accounts have been charged off." ${ }^{20}$ Anyone who has ever attempted to get information about their zombie loan has experienced the frustration of trying to determine who and what you owe. No one will tell you the status of your account. The only thing clear about a zombie loan is that

\footnotetext{
${ }^{16}$ Kate Berry, CFPB Takes Aim at 'Zombie' Foreclosures, MorTgage SeRvicing NEWS, (Sept. 29, 2014), available at, http://www.nationalmortgagenews.com/news/servicing/cfpb-takes-aim-at-zombie-foreclosures1041319-1.html. In the year prior to this announcement the author was approached by the CFPB on this issue and asked to discuss and share data. I shared all my findings with the agency.

${ }^{17} I d$.

${ }^{18} I d$.

19 "Charged off" is an accounting term to refer to the act of moving the debt from accounts recievable to losses. It does not, however, mean the debt is no longer owed.

${ }^{20}$ Mortgage Banking, Allowance for loan and lease losses, Internal Control Questionnaires and Verification Procedures, (visited April 21, 2015; 11:56 a.m.). http://www.occ.gov/publications/publications-bytype/comptrollers-handbook/_paginated/icq/default.htm.
} 
it has extremely negative effects on communities, especially low income communities ${ }^{21}$ and the homeowners left in possession.

\section{a. The Abandoned Mortgage}

No one is particularly troubled when a lender chooses never to foreclose and the homeowner remains in the home throughout the process. ${ }^{22}$ Although this may be an abandoned foreclosure and ultimately both the lender and homeowner may suffer harm, it appears to be a consensual relationship between two contracting parties. The abandoned foreclosures of concern are those in which the lender initiates, but fails to complete the foreclosure. While easier to document in judicial foreclosure states, ${ }^{23}$ the phenomena is being reported in non-judicial states as well. ${ }^{24}$ These abandoned foreclosures often result in abandoned properties. They pose a number of problems for the homeowner and the community.

A lender will rarely tell an individual homeowner that the foreclosure has been abandoned, despite the federal guidance requiring such notice. ${ }^{25}$ As a result, the homeowner often leaves the residence mistakenly believing that title to the home has passed to the bank. The

\footnotetext{
${ }^{21}$ See., i.e., Unresolved Forecloses: Patterns of Zombie Properties in Cook County, WoODSTOCK INST. 5 (January 2014), available at http://www.woodstockinst.org/sites/default/files/attachments/140123_unresolved_foreclosures_final_0.pdf (finding that, in Cook county, Illinois, "[p]properties in census tracts in the bottom three income quintile were more than 10 percent more likely to become zombie properties than were properties in census tracts in the top two quintiles."; Allison Fitzgerald, 'Zombie' homes haunt Florida Neighborhoods: Aborted foreclosures leave thousands of properties in legal limbo, THE CENTER FOR PUBLIC INTEGRITY, http://www.publicintegrity.org/2014/09/15/15519/zombie-homes-haunt-florida-neighborhoods (zombie foreclosures are "more common in Cleveland and the rust belt cities" because banks do not want to "foreclosure because of low value”. In St. Petersburg, Florida, one official who has collected a database of zombie mortgage reports they are "heavily concentrated in the poorer, African-American neighborhoods.).

${ }^{22}$ Investors might be troubled if they knew this was occurring but as of yet they have not voiced these concerns.

${ }^{23}$ There are generally two systems for foreclosure in America. In judicial states, an action must be brought in court to foreclose the mortgage. In nonjudicial states, a trustee is designated to sell the property in case of default. For a summary of the laws of each state and the district of Columbia, see NAT'L CONSUMER LAW CENTER, ForEClOSURES AND MORTGAge SERVICING, $5^{\text {th }}$ ED. APP. F 963-85 (2014)

${ }^{24}$ Foreclosure is primarily non-judicial in California and North Carolina, both of which appear in RealtyTrac's top ten states for zombie foreclosures. See chart one, supra page 2.

${ }^{25}$ Kate Berry, Banks Halting Foreclosure to Avoid Upkeep, AM. BANKer April 23, 2013, available at http://www.americanbanker.com/issues/178_78/banks-halting-foreclosures-to-avoid-upkeep-10585581.html?zkPrintable=true.
} 
lender typically decides not to proceed with foreclosures for economic reasons. ${ }^{26}$ As one Federal Reserve economist put it, "It may cost more to cure the back taxes and bring the property up to code than they could ever get from selling the property itself." ${ }^{27}$ In addition, there are significant costs in owing the property. ${ }^{28}$ A lender's ability to repackage the loan and sell it back into the market provides another incentive to abandon a nonperforming mortgage loan. ${ }^{29}$

There are a number of ways in which a lender can abandon a foreclosure. The first of these might best be called a stalled, as opposed to an abandoned, foreclosure. It occurs when the foreclosure is filed, but the bank neither proceeds nor dismisses the action. ${ }^{30}$ It is not clear whether these loans are actually abandoned or if the lender is simply waiting for conditions to improve before proceeding. ${ }^{31}$ In a previous article I introduced Nick, a client of the Notre Dame Economic Justice Project, and victim of a stalled foreclosure. ${ }^{32}$ A foreclosure was initiated on his home in 2010, but the bank took no action for several years. ${ }^{33}$ He appeared in a New York Times article in 2012 in an attempt to incentivize the bank to respond to his inquiries. ${ }^{34}$ The strategy worked and the bank began negotiating a loan modification. The loan servicer finally

\footnotetext{
${ }^{26}$ The Examination procedures issued by the Federal Home Finance Agency Office of Inspector General requires a bank to make "[a] comparison of the option of continuing the foreclosure or abandoning the foreclosure, considering the cost and potential recovery in a net present value analysis.” EXAMINATION PROCEDURES FOR REVIEWING A Banking Organization'S Abandoned Foreclosure Process, Federal Home FinanCe OfFice OF Inspector GENERAL, http://www.federalreserve.gov/bankinforeg/srletters/sr1211.pdf

${ }^{27}$ Berry, supra note 25. (citing Thomas Fitzpatrick economist, Federal Reserve Bank of Cleveland).

${ }^{28}$ Waldron, supra note 3 at 40.

${ }^{29}$ See, Judith Fox, The Foreclosure Echo: How Abandoned Foreclosures are Re-entering the Market through Debt Buyers, 26 Loy. CONSUmer L. Rev. 25 (2013); Kate Berry, Banks Shedding Distressed loans at higher prices, AM. BANKER, March 1, 2013 http://www.americanbanker.com/issues/178_42/banks-shedding-distressed-loans-athigher-prices-1057170-1.html.

${ }^{30}$ Susan Saulny, When Living in Limbo Avoids Living on the Streets, N.Y. TIMES, March 3, 2012, http://www.nytimes.com/2012/03/04/us/when-living-in-limbo-avoids-living-on-the-street.html?_r=0.

31 There is increasing evidence that these loans are being held to be packaged and re-sold. The banks apparently prefer to sell them as underperforming loans, than judgments. See i.e., Berry, supra note 29 (reporting that in January and February of 2013 "sales of over 5.2 billion" in nonperforming residential loans).

${ }^{32}$ See, supra note 29 at 39-41 (story of Nick, one such homeowner).

${ }^{33}$ Saulny, supra note 30.

${ }^{34}$ Id.
} 
offered Nick a loan modification, but one that capitalizing over $\$ 60,000$ in interest and fees, most of which can be attributed to the years in which the lender failed to foreclose; yet it refused to accept payment on the debt. ${ }^{35}$ This new, capitalized principal balance was not only significantly more than Nick had originally borrowed, it was double the value of the home. He declined the offer. The bank attempted to proceed with the foreclosure in 2014, but has not been able to provide the court with the documentation needed to substantiate its claims. ${ }^{36}$ This zombie will not die. ${ }^{37}$

Florida has the highest number of these stalled foreclosures. ${ }^{38} \mathrm{~A}$ task force commissioned by Florida's Trial Court Budget Commission set out to determine the cause of the stalled foreclosures and to craft strategies to move them through the foreclosure process. They identified two causes for the backlog: "paperwork and procedural problems ${ }^{39}$ and plaintiffs who "do not appear to be inclined to seek disposition of pending foreclosure cases in an expeditious manner." ${ }^{40}$ The judicial system is well equipped to deal with the former, even if some courts have been reluctant to do so. It is harder to see how any state court system can fully address the later issue while the underlying financial incentives to abandon foreclosures remain.

\footnotetext{
${ }^{35}$ For a discussion on mitigation of damages, see infra pp. 32.

${ }^{36}$ Nick is one of several clients of the Economic Justice Clinic, the clinical program at the Notre Dame Law School, who have consented to have their stories told in an effort to help solve the problem of zombie mortgages.

${ }^{37}$ See infra pp for some specific strategies for dealing with this kind of zombie.

${ }^{38}$ See chart 1 , infra page 2.

${ }^{39}$ Florida has had major problems with robo-signing and falsified paperwork. See, i.e. Alan M. White, Losing the Paper-Mortgage Assignment, Note Transfers and Consumer Protection, 2, LOY. CONSUMER L. Rev. 468, 486 (2012) (finding that Florida foreclosures involving MERS more likely to become zombie loans); Kimberly Miller, Florida Supreme Court Disbars Foreclosure King David J. Stern, PALM BEACH Post, January 9, 2014, http://www.mypalmbeachpost.cm/news/business/real-estate/fla-supreme-court-disbars-foreclosure-king-davidj/nchLs/ Todd Ruger, Top Foreclosure Lawyer Shuts down firm, HERALD TRIB. March 7, 2011, http://wwwheraldtribune.com/article/20110307/WIRE/110309586 (describing the saga of David Stern and his law firm whom many feel was responsible for much of the faulty paperwork in Florida).

${ }^{40}$ Foreclosure Backlog Reduction Plan For The State Courts System: Recommendations Of The FORECLOSURE INITIATIVE WORKGROUP, April 10, 2013, 15, http://www.flcourts.org/administration-funding/courtfunding-budget/mortgage-foreclosure.stml.
} 
A clearer picture of an abandoned foreclosure is presented when the lender files a foreclosure, obtains judgment, and never sets the property for sheriff's sale. ${ }^{41}$ It was this scenario that Michelle Conlin of Reuters first dubbed "zombie mortgage." ${ }^{2}$ A closer look at some of these cases illustrates the problem for both homeowners and courts. A study of all foreclosures filed in Allen and St. Joseph Counties, Indiana during 2010 reveal a significant number of abandoned foreclosures. These fall into two categories: those that were initiated and then dismissed and those that went to judgment but the sheriff sale was either never set or set and then cancelled. Chart 2, below, illustrates the abandoned foreclosures found in the 2010 filings.

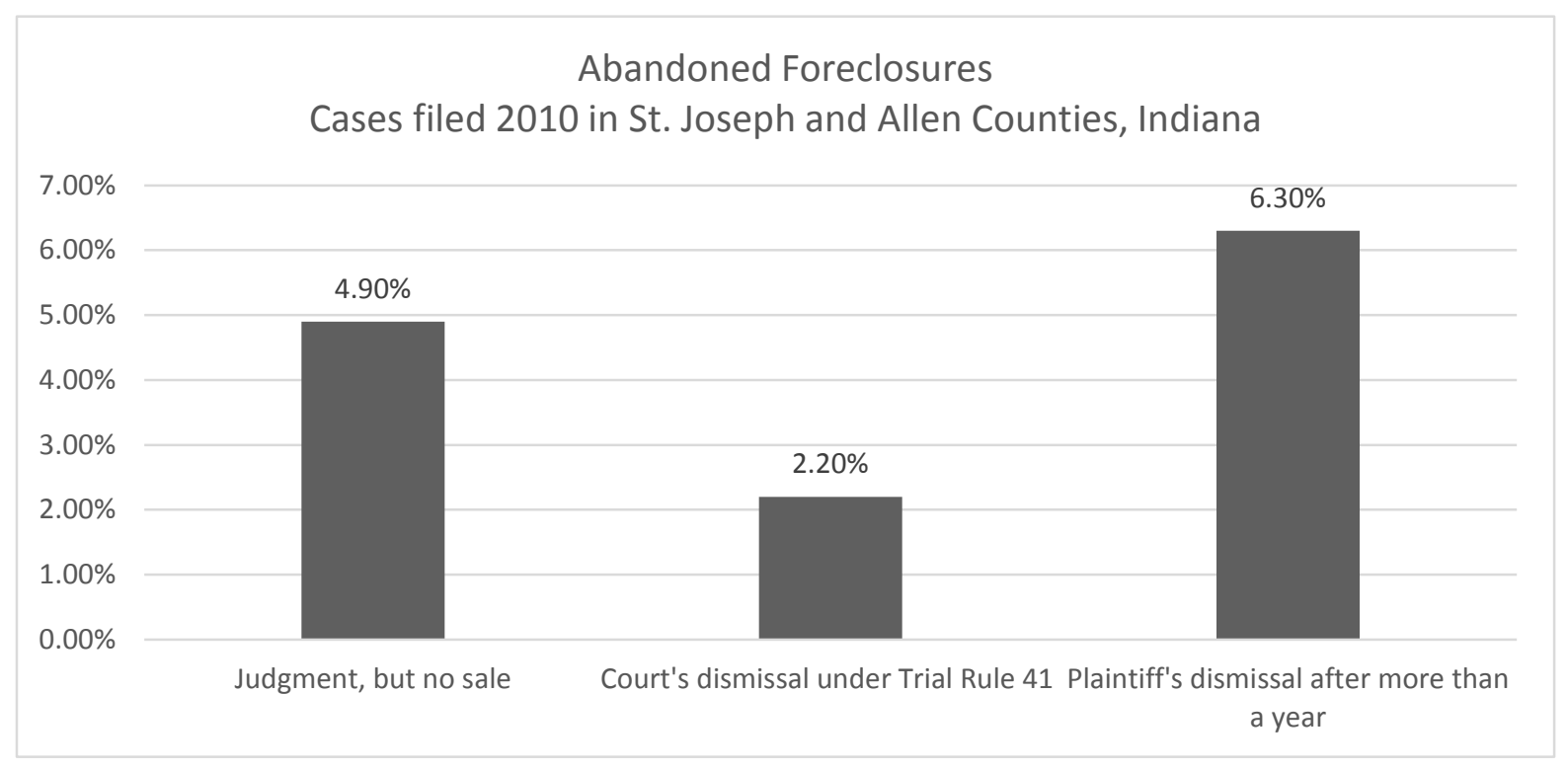

Chart II: Abandoned foreclosures filed in St. Joseph and Allen County, Indiana 2010

\footnotetext{
${ }^{41}$ Les Christie, Zombie foreclosures: Borrowers hit with debts that won't die, http://money.cnn.com/2013/02/20/real estate/zombie-foreclosures/; Conlin, supra, note 3; Sandra Livingston, Bank 'walkaways from foreclosed homes a growing, troubling trend, THE PLAIN DEALER (last updated July 19, 2009, 6:33 PM), http://blog.cleveland.com.metro/print.html?entry=/2009/07/bank_walkawys from_foreclosed.html; Mary Ellen Podmolik, More banks walking away from homes, adding to the housing crisis, CHI. TRIB., Jan. 13, 2011, http://articles.chicagotribune.com/2011-01-13/news/ct-biz-0113-walkaway-20110113_1_foreclosure-processforeclosure-filing-servicers;Susan Saulny, Banks Starting to Walk Away on Foreclosure, N.Y. TimES, March. 30, 2009 at A20, available at http://www.nytimes.com/2009/03/30/us/30walkaway.html?

${ }^{42}$ Conlin, supra note 3.
} 
It was not uncommon to have the foreclosure sale cancelled multiple times, only to be held years after the foreclosure. For that reason, some of these cases may be stalled and not abandoned. ${ }^{43}$ While the percentages of foreclosures that fall into this category appear small, they translate into many homes. In 2010 at least 133 foreclosures in 2 of 92 Indiana counties were stalled or abandoned. If you have even similar numbers over the other 90 counties and the remaining nearly twenty years of the mortgage crisis in Indiana, it is easy to see that Indiana has tens of thousands of abandoned foreclosures. ${ }^{44}$ And this is just Indiana. The numbers are greater in states like Florida, New York and New Jersey. ${ }^{45}$

It is impossible to trace whether all of these abandoned foreclosures have now become abandoned properties because not all municipalities record their abandoned properties. However, research has shown that an increase in foreclosure activity corresponds with an increase in abandoned properties. ${ }^{46}$

\section{b. The "Zombie" mortgage}

An abandoned foreclosure is a nasty problem to solve, but a real zombie mortgage is an even more damaging character. This paper will focus on two iterations of the zombie mortgage. The first is when a homeowner tenders a deed in lieu of foreclosure or the lender purchases the home from the deed of trust's trustee and the lender never records the property transfer. The homeowner has taken action to complete a transfer, but the lender or trustee under the deed of trust fails to take the additional steps to transfer title to the property. The homeowner remains in

\footnotetext{
${ }^{43}$ The data was collected from doxpop, an online docket service and Odyssey, Indiana's state court online docket, during the months of March and April, 2015.

${ }^{44}$ Matt R. Kinghorn, Indiana’s Ongoing Foreclosure Crisis, 86 IND. Bus. REV. (2011), http://www.ibrc.indiana.edu/ibr/2011/summer/article1.html. ( Indiana's foreclosure filing began to rise sharply in 2006 and remained substantially higher than the national average until the rest of the county caught up in 2009);

${ }^{45}$ RealtyTrac, supra note 4.

${ }^{46}$ Judith Fox, Richard Williams \&Brian Miller, Foreclosures in St. Joseph County, Indiana from 2001-2007 (2008) (on file with author).
} 
the owner with all the corresponding rights and responsibilities. These situations are nearly impossible to trace empirically. We are left to rely on antidotal evidence provided by consumers. $^{47}$

The second type of zombie mortgage occurs when a lender forecloses and then months or even years later goes back to the judicial body and sets aside the judgment, re-instating the note. ${ }^{48}$ Notice, if sent at all, is sent to the property address. This is essentially no notice to the homeowner because the property has been abandoned, and the lender usually knows this. Evidence of this zombie mortgages can be found throughout the judicial records. Returning to the study group, 318, or $10 \%$, of the foreclosure judgments were later vacated by the bank. As chart III below demonstrates, when you combine the stalled, abandoned and zombie foreclosures in St. Joseph and Allen Counties, Indiana you get a bleak picture of the housing recovery, but one that closely tracks RealtyTrac's pronouncements. At least $25 \%$ of all the foreclosures filed in these counties in 2010 have entered this netherworld. ${ }^{49}$

\footnotetext{
${ }^{47}$ See, i.e. Christie, supra note 41 (a homeowner who was told on Christmas Eve that she must move from her home after offering a deed in lieu. She moved, but the bank never proceeded with the transfer).

${ }^{48}$ For an extensive discussion of these, See, Fox, supra note 29 at 43-62.

${ }^{49}$ The number is likely larger. The 200 dismissals is out of a possible 725 total dismissals. Some of these are the result of settlements reached in the Indiana foreclosure mediation program. Unfortunately, there are not accurate statistics, nor are the settlements reflected on the court docket sheets. I chose to use the one year cutoff because it is unlikely that a loan modification or payoff would have occurred after that much time. Therefore, it is likely that more than 200 are actually abandoned foreclosures.
} 


\section{Stalled, Abandoned and Zombie Foreclosures}

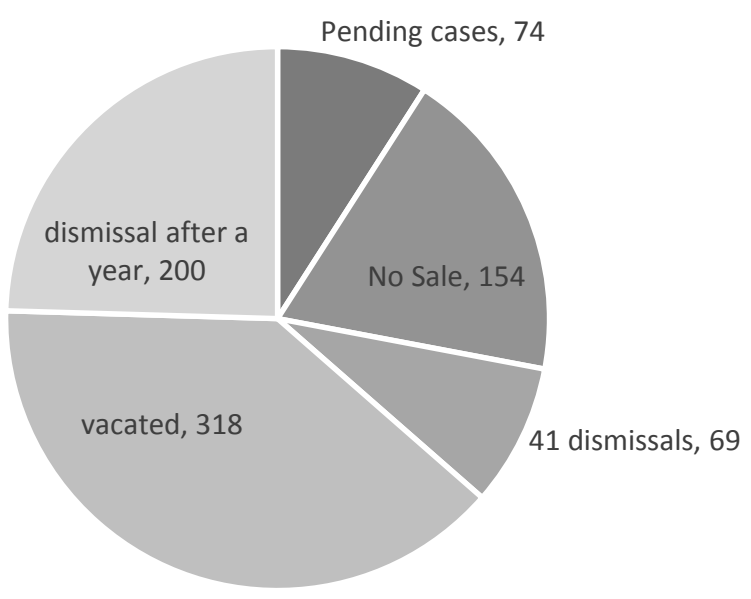

Chart III: Stalled, Abandoned and Zombie Foreclosures from St. Joseph and Allen County, Indiana 2010

Before beginning to address the strategies to assist homeowners it is important to recognize the harms caused by stalled, abandoned and zombie foreclosures. A conversation with any of these homeowners will make one thing very clear: the situation is very stressful. There are tangible damages as well. Multiple reports in the media have documented the surprise homeowners experience when discovering they were fined for failing to maintain a property they did not know they owned. ${ }^{50}$ Interest and fees continues to accrue on the property, but the lender will not accept any money to reduce the debt. Home owner association fees continue to accumulate. ${ }^{51}$ Research has shown that credit scores are reduced and stay reduced for a number

\footnotetext{
${ }^{50}$ See i.e. Saulny, supra note 30 (story of Mercy, a homeowner who was being charged with the cost of demolishing a building after she had agreed to the foreclosure and received notice of the sheriff's sale that never actually occurred); Livingston, supra note 41 (story of Renetta who thought she had lost her home only to be billed, 5 years later, for over $\$ 12,000$ in demolition costs).

${ }^{51}$ In re Pigg, 453 B.R. 728, 733-34 (Bankr. M.D. Tenn, 2011) (“If the lender never forecloses...homeowner’s liability for the HOA fees continues in perpetuity.)
} 
of years after a foreclosure. ${ }^{52}$ This is certainly exacerbated when a lender reports a homeowner's loan as charged off to a credit bureau. The most challenging issues, however, involve efforts by homeowners who are unable to pay their mortgage debt and want the lender to take back the title to the property.

\section{II. $\quad$ KILLING A ZOMBIE LOAN THROUGH BANKRUPTCY}

The first step in understanding the complexity of the homeowner's plight is understanding the differing roles of the mortgage loan documents. A mortgage loan consists of two instruments: a promissory note and a mortgage or deed of trust that acts as the security for that interest. The promissory note is the instrument that governs the right of the lender to collect payments. The mortgage or deed of trust governs the right of the lender to take possession and sell the property to pay the loan. Neither of these, however, are real property. It is well established in the common law that a property owner cannot abandon real property. ${ }^{53}$ Therein lies the problem.

Some of the earliest controversies involving zombie loans came to light in the context of bankruptcy proceedings. ${ }^{54}$ Many debtors believe that surrendering property in a bankruptcy proceeding relieves them of the burdens of ownership, not just the burden of the mortgage debt.

It does not. ${ }^{55}$ Despite this, a chapter 13 bankruptcy proceeding may still be the only way to force a lender to take ownership of a property. In a chapter 13 bankruptcy the debtor creates a plan

\footnotetext{
52 Kenneth P. Brevoort, and Cheryl R. Cooper, Foreclosure's Wake: The Credit Experiences of Individuals following Foreclosure, 23-4 http://ssrn.com?abstract=1696103.

${ }^{53}$ Lior Jacob Strahilevitz, The Right to Abandon, 158 U. PA. L. REV.355, 399 (2010).

${ }^{54}$ Andrea Boyack and Judge Robert Berger, Bankruptcy Weapons to Terminate a Zombie Mortgage, 24-50 WASHBURN L. REV. (forthcoming 2015); Kathleen G. Furr and Brett A. Switzer, Silence is Golden: Rose and Its Focus on Real Property Surrendered in Chapter 13, 34 AM. BANKR. INST. J. 18 (2015), Christopher W. Frost, Zombie Titles and Bankruptcy: In re Canning, 33 No. Bankr. Law Letter 1 (June 2013).

${ }^{55}$ In re Watt, No. 14-31295-tmb13 (Bankr. D. Or. 2014) at 2; In re Phillips, 368 B.R.733, 743-44(Bankr. N.D. Ind. 2007).
} 
to restructure or repay all or a portion of his debts. ${ }^{56}$ As part of that plan, section 1322(a) of the bankruptcy code allows a debtor to surrender a secured property to the creditor. ${ }^{57}$ Unfortunately, “surrender does not divest a debtor of ownership and its obligations.” ${ }^{58}$ The creditor can chose whether or not to accept surrender. If it does, it will proceed either to foreclosure on the property or to work out some other transfer of title. If it does not, the property remains the responsibility of the homeowner.

Bankruptcy is grounded in the notion of a fresh start and sometimes the transfer of the property is needed for that fresh start. If this is the case, homeowners are best advised to do more than simply surrender the property. Instead, homeowners should seek the relief offered by Section 1322 (b) of the bankruptcy code. ${ }^{59}$ According to this section, a chapter 13 bankruptcy plan may "provide for the vesting of property of the estate, on confirmation of the plan or at a later time, in the debtor or in any other entity." 60 These two portions of the bankruptcy code use distinctly different terminology. Section 1322(a) gives the debtor the power to "surrender" the property, while section 1322(b) talks about "vesting” the property in the creditor. As the Court in In re Rosa, ${ }^{61}$ pointed out, "courts presume that, when Congress uses different words, it means different things. The plain meaning of “vesting”' includes a present transfer of ownership.”62 The Rosa court then reasoned section 1322(b) gave it the authority to conform a bankruptcy plan that transferred title of the property to the creditor, over the objection of the Trustee and silence

\footnotetext{
5611 U.S.C $\S 1322(20$

5711 U.S.C. $\$ 1325(\mathrm{a})(5)(\mathrm{C})$.

${ }^{58}$ See, Watt, No. 14-31295-tmb13 (Bankr. D. Or. 2014)(chapter 13) and In re Canning, 442 B.R. 165, 175 (Bankr. D. Me. 2011) (chapter 7).See also, In re Phillips 368 B.R. 733 (Bankr. N.D. Ind., 2007) (homeowner remains liable for code enforcement fines despite surrender); In re Pigg, 453 B.R. 728, 733 (Bankr. M.D.Tenn 2011) ("If a lender never forecloses, the homeowner's liability for the HOA fees continues in perpetuity).

5911 U.S.C. §1322(b).

6011 U.S.C. $\$ 1322(\mathrm{~b})$

${ }^{61}$ In re Rosa, 495 B.R. 522 (Bankr. D. Hawaii, 2013).

62 Id. at 524.
} 
of the creditor. ${ }^{63}$ Rosa became the first case to hold that a debtor could transfer the property back to the creditor as part of its chapter 13 bankruptcy plan, but it was not the last. ${ }^{64}$

In re Watt soon followed. ${ }^{65}$ The Watt judge took the Rosa analysis one step further. While the court in Rosa had allowed for the transfer of title, it did so only because it had deemed consent on the part of the creditor when the creditor failed to object to the plan after proper notice. ${ }^{66}$ The Court in Watt found that consent was not necessary. ${ }^{67}$ Instead, it relied on the statute to find that the plan vesting the property in the name of the creditor must be approved so long as it is offered in good faith. ${ }^{68}$ Not all bankruptcy courts have agreed with this analysis. ${ }^{69}$ However, the language of the code is clear and the use of this section of the code is sure to increase.

Because all bankruptcy courts may not accept their ability to vest the property in the creditor as part of the bankruptcy plan, some homeowners will need to look to other portions of the code for relief. Bankruptcy courts are courts in equity. As such, they can use their equity to further the goal of a bankruptcy proceeding: providing a fresh start for the debtor. ${ }^{70}$ In Pigg $v$. BAC Home Loans Serving the court used its equitable power in order to order the Trustee to sell the property. ${ }^{71} 11$ U.S.C. §363(f) allows the bankruptcy court to order the sale of bankruptcy

\footnotetext{
${ }^{63}$ Id. (The silence of the creditor was deemed to be consent).

${ }^{64}$ Kathleen G. Furr and Brett A. Switzer, Silence is Golden: Rose and Its Focus on Real Property Surrendered in Chapter 13, 34 AM. BANKR. INST. J. 18, 18 (2015),

65520 B.R. 834 (Bankr. D. Or. 2014)

${ }^{66}$ In re Rosa, 495 B.R. at 524.

${ }^{67}$ Watt, No. 14-31295-tmb13 at 839.

${ }^{68}$ Id. at 840; But See, In re Rose, 512 B.R. 790 (Bankr. W.D. N.C. 2014) (refusing to force a creditor to take title to the property)

${ }^{69}$ See, In re Rose512 B.R. 790 (Bankr. W.D. N.C. 2014).

${ }^{70}$ In re Pigg, 453 BR 728, 735; see also Boyack and Berger, supra note 54 at 27-28.

${ }^{71}$ In re Pigg, 453 BR 728, 736.
} 
assets free and clear of liens if certain conditions are met. ${ }^{72}$ Like the court in Rosa, the Pigg court found that the lender's inaction in the case constituted consent to the sale. ${ }^{73}$ The justification for the action in the two cases, however, was quite different. According to the court in Pigg, "equity demands that the court fashion a remedy that balances the rights of the lienholders and the right of a debtor to a fresh start." ${ }^{74}$ As with Section 1322, not all courts agree about the breathe of their equitable power. The courts in both In re Fritsoe and in re Arsenault rejected the notion that their equitable power allowed them to order the sale of the property or to compel the creditor to accept title. ${ }^{75}$

Bankruptcy may well provide the best means to defeat a zombie mortgage. Unfortunately, not everyone is eligible for a chapter 13 bankruptcy. A recent Federal Reserve study has found that the 2005 bankruptcy reforms have actually made bankruptcy an option too expensive for those most in need. ${ }^{76}$ Ironically, the best remedy for a zombie foreclosure may not be available in the low-income neighborhoods where most of these foreclosures occur. Homeowners are often forced to forgo the best remedy for a combination of cobbled-together, second and third best remedies.

\section{WHEN BANKRUPTCY IS NOT AN OPTION: KATHLEEN'S STORY}

There are frankly no good options for a homeowner who is trying to wrestle free from a zombie loans, especially for the many low income homeowners who are the most likely victims.

\footnotetext{
${ }^{72}$ Pigg at 736. These conditions are: (1) applicable non-bankruptcy law permits sale of such property free and clear of such interest; (2) such entity consents; (3) such interest is a lien and the price art which such property is to be sold is greater than the aggregate value of all liens on such property; (d) such interest is in bona fide dispute; or (5) such entity could be compelled to accept a monetary satisfaction of such interest.” Id.

${ }^{73}$ Id. at 736

${ }^{74} \mathrm{Id}$.

${ }^{75}$ In re Fritsoe, 2012 WL 4483891 (BR D Utah Sept. 27 2010); In re Arsenault, 456 B 627 (Bankr. S.D. Ga 2011).

${ }^{76}$ Katy Stech, Too Poor to File (for Bankruptcy), WALL STREET J., April 24, 2015, 547 PM ET, available at http://blogs.wsj.com/economics/2015/04/14/too-poor-to-file-for-bankruptcy/.
} 
While the strategies depend largely on what the homeowner is attempting to accomplish, it will soon become clear that those goals must also be flexible.

Kathleen has a classic zombie mortgage. ${ }^{77}$ Her efforts to resolve the situation illustrate the complexities of the problem, but also offers some insights into possible solutions. Kathleen, like so many others, began to have trouble paying her mortgage after a reduction in wages in 2011. She worked with the servicer of her loan, Bank of America, first in an attempt to obtain a loan modification and, when that failed, a deed in lieu of foreclosure. On March 29, 2011 the bank filed a foreclosure action in St. Joseph Circuit Court. ${ }^{78}$ On April 28, 2011 the lender informed her that her application to surrender the home through a deed in lieu of foreclosure had been accepted. ${ }^{79}$ Shortly afterwards, on May 23, 201l, Bank of America asked her to sign a Deed in Lieu packet and Surrender of Possession Agreement and to move from the home. ${ }^{80}$ She complied both in the signing of the document and in vacating the premises. Months passed and she heard nothing regarding the deed in lieu packet. In December of 2011, Bank of America sent her a second packet, which she also completed and returned.

Kathy thought the foreclosure was behind her. She had given the house back to the bank. She could not have been more wrong. The deed in lieu packet was apparently never processed. A default judgment was entered against Kathleen on November 7, 2012. On July 29, 2013, Bank of New York filed a motion to vacate the judgment and re-instate the note and mortgage. ${ }^{81}$

\footnotetext{
${ }^{77}$ Kathleen Carlo is a client of the Economic Justice Project who has given her consent to this article. She currently has two cases pending in the St. Joseph County Circuit Court, causes no. 71-C01-1103-MF-000118 (a foreclosure filed in 2011) and 71-C01-1408-PL-000236 (a quiet title filed in 2014)

${ }^{78}$ Cause no. 71-C01-1103-MF-000118, docket available at http://mycase.in.gov/Search.aspx?. This is a classic example of what has come to be known as "dual tracking," It happens when a servicer is working on loss mitigation options at the same time that the attorney is working on foreclosure. Dual tracking has caused numerous problems and, as a result, is now prohibited.

${ }^{79}$ All documents are part of the public record in 71-C01-1408-PL-000236, St. Joseph Circuit Court.

${ }^{80}$ All documents are part of the public record in 71-C01-1408-PL-000236, St. Joseph Circuit Court.

${ }^{81}$ The request to reinstate the note is to avoid merger. See Fox, supra note 29 at 45-6.
} 
Kathleen never received notice of the motion. There was no hearing because the motion implied that the mortgage was current. The motion indicated that "Plaintiff is no longer proceeding with this foreclosure cause due to insufficient value of the subject real estate.” At the end of the motion, and in a paragraph that the bank now claims was a clerical error, the lender asked the court to "vacate the Judgment dated November 7, 2012 as the Defendants have since resolved the issues stated in said Complaint and the account is now current.” ${ }^{82}$ The foreclosure was set aside and the note and mortgage reinstated. Unbeknownst to Kathy, she not only owned the home; she again had a mortgage.

Another year passed and Kathy remained unaware that the property she thought had been returned to the bank via a deed-in-lieu was, in fact, still in her name. In 2014, she was contacted by the city's building code department because the property had fallen into disrepair. It was only then that she discovered she still owned the property. Despite asking her to sign an agreement to surrender the property, the lender had never taken steps to secure the property against vandals. While it had been unoccupied, all the cabinets and plumbing were removed. The roof had been damaged and mold appeared in the basement. ${ }^{83}$ Kathy immediately took steps to secure the property, but remained confused as to how all this had come to pass.

Kathy's story is a classic example of all that goes wrong in a zombie mortgage. It is also, unfortunately, not atypical. Kathy's home had sat vacant for more than three years. The damage has been done. How can you unwind the situation now? Kathy decided she would try to rebuild the home and move back in; but she feared that as soon as she made the property habitable again the bank would re-appear to foreclose.

\footnotetext{
${ }^{82}$ Motion to Vacate Judgment and Dismiss Cause, filed July 29, 2013, St. Joseph Circuit Court, 71-C01-1103-MF000118.

${ }^{83}$ Carlo v. Bank of New York, amended complaint, 71 C01 1408 PL 000236
} 
It is important to view this situation through the eyes of a homeowner. What had gone wrong? Kathleen first went to the courthouse where she discovered that the foreclosure had been set aside because, according to the motion to vacate filed by the lender "the loan was now current.” This puzzled her because, according to the last information she had received from the bank, she was still in default. She tried to contact the servicer for information but was told they did not have her loan.

\section{a. Request for Information}

This is the first roadblock homeowners with zombie loans encounter. Federal regulations allow a homeowner to request information about their loan, including who owns it. ${ }^{84}$ However, if the loan was discharged in bankruptcy or if the servicer has not been the servicer for more than a year, the lender does not need to reply to the request. ${ }^{85} \mathrm{~A}$ zombie mortgage is likely to fall into this category. As a result, even if the homeowners are willing and able to do a loan workout, they may not be able to identify who to talk to in order to accomplish this.

The next step is to look in the land records. They will most often reveal the mortgage holder as the Mortgage Electronic Registration System (MERS). MERs was created by the mortgage banking industry to ease the transfer of paper in the buying and selling of mortgages. ${ }^{86}$ MERS was delegated as "nominee" for the lender and registered the mortgage in the local land recordation system. The loan could then be sold without the need to continually update the mortgage holder. MERS acted as a place holder, or at least that was how the system was intended to work. Apparently, MERS did not keep accurate accounting of the mortgage transfers

\footnotetext{
${ }^{84}$ Real Estate Settlement Procedures Act, Reg Z, 12 C.F...§1024.36(d)(2); Truth in Lending, 15 U.S.C.§1641(f)(2) 8512 CFR 1024.36(f).

${ }^{86}$ White, supra note 39 at 486 (2012); David H. Carpenter, "Robo-Signing” and other Alleged Documentation Problems in Judicial and Nonjudicial Foreclosure Processes, CONGRESSIONAL RESEARCH SERVICE, November 15, 2010 at 6-7.
} 
or maybe the sales were just happening too quickly. In the end, there were numerous paperwork problems and thousands of foreclosures stalled or abandoned as a result. ${ }^{87}$ Studies of Florida foreclosures, for instance, have shown that involvement by MERS in a loan file made it more likely the loan would end up as a "zombie” loan. ${ }^{88}$

The homeowner has now identified MERS as its mortgagor. She can attempt to contact MERS, but lending institutions, not consumers, are MERS's customers. ${ }^{89}$ MERS does not answer consumer inquiries, even if you did find a way to reach it. The homeowner will have reached another dead end. At this point, most homeowners simply give up. If the property was abandoned, it stays abandoned. If not, the homeowner simply remains in the home, waiting for the other shoe to drop. A homeowner in this situation is very unlikely to invest in home improvements or even routine maintenance. The property declines and with it the property values of neighboring homes. ${ }^{90}$

\section{b. Quiet Title}

Quiet title offers a possible way for homeowners to remove a zombie mortgage. A quiet title is an equitable action used to clear a cloud in the title of a property, but it is not appropriate in every situation. ${ }^{91}$ Because quiet title is an equitable action "a plaintiff who seeks quite title must come to court with clean hands." ${ }^{92}$ A quiet title is best used when the promissory note is no longer valid, as when the statute of limitations has passed or the obligation has been discharged

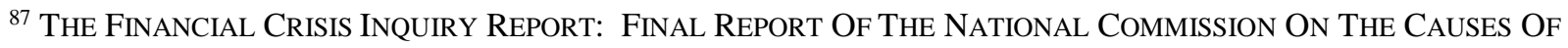
The FinanCial AND EConomic CRisis In The United StATES, 407 January 2011.

${ }^{88}$ White, supra note 39 at 486.

${ }^{89}$ MERS has a website that claims to be able to tell a homeowner who owns their loan. I have attempted to do this, unsuccessfully, countless times.

${ }^{90}$ Elliot Anenberg and Edward Kung, Estimates of the size and source of price declines due to nearby foreclosures 104 AM. ECON. REV. 247, 255 (2014) (finding that in high density neighborhood the lack of maintenance of homes in foreclosure contribute to lower property values).

${ }^{91}$ Wolff v. Bank of N.Y. Mellon, 997 F. Supp 964, 978 (D. Minn. 2014) (finding that a homeowner in default cannot make a claim for quiet title).
} 
in a chapter 7 bankruptcy. ${ }^{93}$ In some cases, though, a quiet title is the only option left to determine who is the mortgage holder and the extent to which anyone is claiming an interest in the property. ${ }^{94}$

When the statute of limitations has expired on the note, an action in quiet title would seem clear cut. There is no enforceable debt, so there should be no enforceable lien to support that debt. Unfortunately, the situation is not that simple. At some point after a homeowner goes into default on a mortgage loan the lender will notify him that it will no longer accept monthly payments. Instead, it has accelerated the note and the entire principal balance of the loan is due. Failure to pay will bring foreclosure.

As previously mentioned, a mortgage loan consists of two documents: the promissory note, nearly always a negotiable instrument, and the mortgage or deed of trust. Determining the statute of limitations for a mortgage loan sometimes means reconciling these two instruments. Some states, such as New York, have a statute of limitations that applies to both the mortgage and the note. ${ }^{95}$ Kathleen's home state of Indiana has two separate statutes, with two different statutes of limitations. A mortgage expires in Indiana ten years after the last payment on the note was due, unless "action to foreclose is brought not later than ten (10) years after the last installment of the debt." ${ }^{\prime 6}$ Under §3-118 of the uniform commercial code, which Indiana has

\footnotetext{
${ }^{93}$ See, i.e. Westar Funding, Inc. v. Sorrels, 239 P.3d. 1109 (Wash. App. 2010); Walcker v Benson and McLaughlin, 904 P.2d 1176 (Wash. App. 1995).

${ }^{94}$ In the rare instance where you have a mortgage holder that no longer exists and has not passed on its interest, quiet title can also be effective. The Economic Justice Clinic has successfully used quiet title in a situation where a loan was made by a now defunct bank. The transfer of the mortgage was invalid, having been forged. The lender filed and then dismissed a foreclosure, with prejudice. No one had accepted money for several years and the institution that appeared on the record as mortgage holder did not appear to contest the quiet title action.

${ }^{95}$ N.Y. C.P.L. R. $\$ 213$ (McKinney 2012), six year statute of limitation for a mortgage

${ }^{96}$ IND. CODE §32-28-4-1 (Burns 2015).
} 
adopted, the statute of limitation of the promissory note expires six years after default, or if the note is accelerated, six years after acceleration. ${ }^{97}$

Acceleration and the subsequent foreclosure action are key to the analysis. Kathleen’s mortgage was accelerated by the bank in 2011. ${ }^{98}$ Under the uniform commercial code, Ind. Code 26-1-3.1-118, it is clear that the statute of limitations began to run in 2011 as to payment on the note. Under the plain meaning of the statute, the clock also began to run on the enforcement of the mortgage because a foreclosure was filed. Under Indiana law this is a ten year period. ${ }^{99}$ Yet, whether or not that applicable time period to foreclose should be ten or six years has never been decided in Indiana. ${ }^{100}$ A logical way to resolve this apparent conflict would be to apply the six year statute of limitations on the ability to collect money and the ten year period to the mortgage and the ability to sell the home in foreclosure. Under that reasoning a lender could re-foreclose on a zombie loan more than six, but less than ten, years after the acceleration of the note, but only in rem. This seems logical, but it too conflicts with other areas of the law. In Indiana, as in most states, " $[\mathrm{t}]$ debt is the principal, and the mortgage the surety; and a nullity without the debt.” ${ }^{101}$ You cannot foreclosure on a mortgage if the note is unenforceable. ${ }^{102}$

With regard to a zombie loan, the real controversy involves what happens after the bank accelerates the note, forecloses and then "reinstates the mortgage and the note.” Does setting

\footnotetext{
${ }^{97}$ IND. CODE §26-1-3.1-118 (Burns 2015).

${ }^{98}$ In her case, and in violation the mortgage documents, the foreclosure was filed the same day as the letter accelerating the debt.

${ }^{99}$ IND. CODE §32-28-4-1(Burns 2015).

${ }^{100}$ There is no case that has directly addressed this issue. Alfolabi v. Atlantic Mortg. \& Investment Corp, 849 N.E.2d. 1170, 1175 (Ind 2006) came close. It held that "res judicaa does not bar successive foreclosure claims, regardless of whether or not the mortgagee sought to accelerate payments on the note in the first claim.” This case, however, was argued on the grounds of claim preclusion. No one asked the question regarding the conflicting statutes of limitations. It is not clear how this case would have been decided if the second foreclosure claim had been filed beyond the 6 year statute of limitation triggered by the acceleration.

${ }^{101}$ Leader Pub.Co. v. Grant Trust \& savings, 91 N.E. 498 (Ind. 1910); See also, Ewell v. Daggs,108 U.S. 143, 147 (1883) ('If that debt is barred by the statute of limitations, he foreclosure suit is barred").

${ }^{102}$ See Elizabeth Renaurt, Uneasy Intersections: The Right to Foreclosure and the UCC, 48 WAKE FOREST L. REV. 1205 (2013).
} 
aside the foreclosure automatically decelerate the note? In thirteen states the answer is "no." 103 If the note is decelerated the lender has the ability to sue and dismiss over a period of years. In my review of foreclosure files, I have found multiple examples of lenders doing just that. Below a just a few examples:

\begin{tabular}{|l|l|l|l|l|}
\hline First Foreclosure Action & Sale & $\begin{array}{l}\text { Judgment set } \\
\text { aside; } \\
\text { foreclosure } \\
\text { dismissed }\end{array}$ & Second Foreclosure Action & Sale \\
\hline $\begin{array}{l}\text { 49-D131-1202-MF-7141 } \\
\text { July 10, 2012 } \\
\text { Judgment: } 69359.49\end{array}$ & $\begin{array}{l}\text { Set and } \\
\text { cancelled } \\
\text { October } \\
2012\end{array}$ & November 2012 & $\begin{array}{l}49-D 12-1212-M F-47615 \\
\text { November 6, 2014 } \\
\text { Judgment: 79384.79 }\end{array}$ & $\begin{array}{l}\text { February 2015; } \\
\text { deficiency balance }\end{array}$ \\
\hline $\begin{array}{l}\text { 71-C01-1509-MF-678 } \\
\text { June 19, 2006 }\end{array}$ & $\begin{array}{l}\text { Set and } \\
\text { Judgment: }\end{array}$ & $\begin{array}{l}\text { December 23, } \\
2013\end{array}$ & $\begin{array}{l}\text { 71-D07-1409-MF-000477 } \\
\text { Refiled December 23, 2013 } \\
\text { (no judgment yet) }\end{array}$ & \\
\hline $\begin{array}{l}\text { 71-C01-1010-MF-600 } \\
\text { December 22, 2010 } \\
\text { Judgment: 22644.22 }\end{array}$ & $\begin{array}{l}\text { Set and } \\
\text { cancelled } \\
\text { June 2011 }\end{array}$ & June 15, 2011 & $\begin{array}{l}71-C 01-1010-M F-600 \\
\text { August 30, 2011 } \\
\text { Judgment: 31754.52 }\end{array}$ & \\
\hline
\end{tabular}

Chart IV: Examples of serial filings of zombie mortgages

None of the above homeowners were aware that either the sale was cancelled or that the foreclosure was subsequently dismissed. In the first, the refiling resulted in a judgment of more than $\$ 10,000$ greater than the first, all in interest and fees. The second homeowner is still litigating his action, but his second foreclosure appears to have been filed beyond the statute of limitations of the note. Finally, the last homeowner was deceased, so clearly he did not consent to any of the actions in the case. The harm is to the unknown heirs and the integrity of the

\footnotetext{
103 See, brief of the Amici Curiae National Association of Consumer Advocates, The National Consumer Law Cener and the Jerome N. Frank Legal Services Organization, Bartram v. U. S. Bank, Case No. SC14-1265, Supreme Court of Florida. (Those states being Arizona, Arkansas, Connecticut, Louisiana, Maine, Nevada, New Jersey, New Mexico, New York, Texas, Washington, Kentucky and Ohio). But see, Leonard v. Ocwen Loan Servicing, 2014 WL 4161769, at 2 (S.D.Texas 2014 )(the act of sending a new statement that requested less than the full balance acted to abandon the acceleration).
} 
judicial system. As with the first borrower, the second judgment is larger than the first because of new filing fees and attorney costs.

Step away from the world of foreclosure for a moment. Suppose, instead, the plaintiff is the victim of a car accident who is suing the driver of the other car for damages. He wins an award of \$22,644.22, as in our last example above. He then he decides that if he waits a year or two, he might get a better deal. He asks the court to set aside the judgment without prejudice and then he re-files the same action year later, this time obtaining a judgment of $\$ 31,754.52$. Is there any court in the country that would allow a plaintiff this liberty? No. Jurisprudential rules regarding res judicata and finality of judgments would certainly prevent it. Yet, banks are being allowed to do just this, over and over again across the country.

\section{c. Fraud on the Court}

The question must be asked. Why? The most obvious reason, and the reason that plays out when these files are examined, is that the plaintiff/lenders are misrepresenting their actions to the courts. ${ }^{104}$ In Kathleen's case, the motion to set aside the judgment represented to the court that the "account was now current." 105 The judge, believing that the parties had reached a loan modification, relied on that statement to set aside the judgment. ${ }^{106}$ After filing the quiet title, the lender returned to the foreclosing court (coincidentally the same court that is handling the quiet title) and asked that the language in the motion be removed because it was a clerical error. ${ }^{107}$ The language may or may not have been a clerical error in Kathleen's case. However, the pattern of

\footnotetext{
${ }^{104}$ It is exceedingly hard to find these motions. Once a file is dismissed, most courts destroy the paper files. While federal court filings are preserved electronically, few state court files are so preserved. Federal courts do not tolerate this kind of action, so these cases are appearing predominately in state court. Despite this, relentless digging in soon to be destroyed files have produced numerous copies of the motions and the stated reasons for dismissal.

${ }^{105}$ Motion Vacate...

${ }^{106}$ The judge made this point at two subsequent hearings, one on and another on. In fact, but for that statement, he indicated that he would have required a hearing on the motion.

${ }^{107}$ Motion to Vacate Judgment and Dismiss Case, filed July 29, 2013, St. Joseph Circuit Court, 71-C01-1103-MF000118 .
} 
these misrepresentations by different lenders and in differing jurisdiction suggests that the decision to misrepresent facts to courts in these cases is no error. This is an intentional strategy to undo foreclosures without tipping off the judiciary as to what is really going on.

Motions to vacate judgments often imply that the parties have resolved their dispute, suggesting to the judicial officer that either the loan was brought current or that a loan modification is in place. Phrases such as "the parties have reached a resolution of all disputed issues," found in one St. Joseph County case, are common. ${ }^{108}$ When the homeowner appeared at the hearing in this case, he disputed that a settlement had been reached. The attorney then changed the argument and suggested that the true reason for filing the motion to vacate was "to make it easier for the new attorneys representing our client.”109 This statement may well have been the truth. A review of state court mortgage filings suggests that some of these zombie mortgages were created at or around the time that the servicers or their attorneys changed.

This may explain how Mr. Miller (the second example in chart four) ended up with a zombie loan. ${ }^{110}$ His first foreclosure was filed by Mortgage Electronic Registration System in 2012 by one law firm located in Merriville, Indiana. ${ }^{111}$ The sale was set, cancelled and then the foreclosure set aside. Two years later, Bank of America, represented by a law firm located in Cincinnati, Ohio refiled the foreclosure. ${ }^{112}$ The lender had no contact with the bank in between these two filings. ${ }^{113}$

\footnotetext{
${ }^{108}$ Order, MERS v. Schwartz, 71 D05 0601 MF 000200 (order denying Motion to Vacate judgment because it was clear to the court that the "statement in the Motion to Vacate Judgment as to the basis of the Motion was false"). ${ }^{109}$ Id.

${ }^{110}$ Supra page 24.

${ }^{111}$ MERS v. Miller, 49-D131-1202-MF-7141, Marion County Superior Court.

112 Bank of America v. Miller, 49-D12-1212-MF-47615, Marion County Superior Court.

${ }^{113}$ Email exchange with homeowner's attorney, Crystal Francis, March 2015.
} 
In other cases, however, the motivation for the lender's action is less clear. In JP Morgan Chase v. Pinkert, the lender failed to state any reason for its request to vacate the judgment. ${ }^{114}$ In the hearing set by the court on the matter, the attorney first claimed that the judgment needed to be vacated to allow for loss mitigation. ${ }^{115}$ He was left scrambling when the judge pointed out that the homeowner was deceased and, therefore, not likely to engage productively in loss mitigation efforts. ${ }^{116}$ What is clear from these and numerous other such motions is that the creditor rarely aligns the reason for the request with the court rules that governs such actions. ${ }^{117}$

Instead, lenders supply no reason or false reasons to induce the court to take a particular action, vacating the judgment previously awarded to the lender. The deceptive nature of these motions may give rise to a separate cause of action: fraud on the court. Fraud on the court is narrowly defined. ${ }^{118}$ It is "an egregious offense against the integrity of the judicial system” and requires some “unconscionable scheme calculated to interfere with the judicial system’s ability to impartially adjudicate a matter by improperly influencing the trier of fact.” ${ }^{119}$ Fraud on the court requires a finding of intent. The intent to deceive is necessary, but not sufficient. The court must have actually taken the intended action. ${ }^{120}$ It is fairly easy to establish that a motion

\footnotetext{
114 Transcript, JP Morgan Chase v. Pinckert, 71 D05 1209 MF-000529, p. 3-5 (on file with author).

115 Transcript, JP Morgan Chase v. Pinckert, 71 D05 1209 MF-000529, p. 3-5 (on file with author).

116 Id.

${ }^{117}$ FED. R. CIV. P. 60 ( Thomas Reuters 2015) The rule provides the following allowable reasons for setting aside a judgment:

(1) mistake, inadvertence, surprise or excusable neglect

(2) newly discovered evidence that, with reasonable diligence, could not have been discovered in time to move for a new trial under Rule 59(b)

(3) fraud (whether previously called intrinsic or extrinsic), misrepresentation, or misconduct by opposing party

(4) the judgement is void

(5) the judgment has been satisfied, released or discharged; it is based on an earlier judgment that has been reversed or vacated; or applying it prospectively is no longer equitable; or

(6) any other reason that justifies relief.

118 C.R.”Chip” Bowles, Jr., It's Not Nice to Fool Mother Nature...Or the Courts 28-Apr AM. BANKER INST. J. 42 (2009).

${ }^{119}$ Wells Fargo Bank v. Reeves, 92 So. 2d. 249, 252 (D. Florida 2012).

${ }^{120}$ Stonger v. Sorrell, 776 N.E.2d 353, 358 (Ind. 2002)
} 
claiming the parties are engaging in loss mitigation with a homeowner when no such efforts were underway was intentionally deceptive. Courts favor loss mitigation efforts and are very inclined to set a aside a judgment to facilitate such activity. Proving an "unconscionable scheme," however, is much more difficult, time consuming and expensive. Frankly, who but a law professor has the time to search thousands of state court records looking for a pattern of deception in the setting aside of zombie mortgages?

The proper way to vacate a judgment is with a motion under Trial Rule 60. ${ }^{121}$ Except in rare circumstances, such a motion must be brought within one year of the judgment and must state a reason to justify the action. ${ }^{122}$ An allegation of fraud on the court is best raised in opposition to the creditor's motion to vacate the judgment. Homeowners with zombie loans have abandoned their property because they believe it has been foreclosed. Most never receive a copy the motion. These leaves the party best equipped to raise fraud on the court, the court itself.

It is an unusual for a defendant to oppose a motion to set aside a judgment that has been entered against him and, as a result, there is virtually no case law addressing this specific situation. This fact adds to the homeowner's problem. Judges are simply not accustom to a situation where the plaintiff creditor no longer wants a judgment to remain in place and the defendant debtor does. In granting these motions, courts seem to be making the logical, but in this case erroneous, assumption that their action will benefit the defendant, homeowner. They grant the motion, almost always without a hearing.

If, however, the homeowner does gain knowledge of the events, fraud on the court can be an especially useful tool for convincing the court to not only grant the motion to set aside the

\footnotetext{
${ }^{121}$ See Fox, supra note 29 at $46-49$ for an extensive discussion of the use and misuse of trial rule 60 in this context

${ }^{122}$ Id. In my review of files, I have only seen one instance when rule 60 was cited.
} 
judgment, but also dismiss the foreclosure with prejudice as a sanction for the lender's fraudulent actions. ${ }^{123}$ A dismissal with prejudice may prevent the serial foreclosure problem that not only adds to the homeowner's ultimate costs, but wastes precious judicial time and resources. If the motion to vacate the judgment and dismiss the foreclosure action is being made for a legitimate purpose and not simply to postpone the judgment until the bank feels it can achieve a better result, the lender should not object to a dismissal with prejudice.

There are traditionally three ways to raise fraud on the court. ${ }^{124}$ A party can file a motion under trial rule 60(b) (3) alleging the fraud. ${ }^{125}$ If the homeowner does not discover the subsequent action within a year, the next available method is to file an independent action under 60(b). ${ }^{126}$ With zombie mortgages the homeowners will most likely be asking the court to set aside the order granting the motion to vacate. Ironically, their request will actually result in enforcing, as opposed to setting aside, the foreclosure judgment. Finally, if neither of these are available, a court has the inherent power to set aside an order or perhaps refuse to grant it in the first place, if the relief being sought is "procured by fraud on the court."127 A court can, therefore, set aside its order sua sponte if it discovers a pattern of fraud on the court in the presentation of the motion to vacate judgment. Based on the court's ability to raise this sua sponte, a homeowner should also be able to raise the issue as a shield, not a sword, and ask the court not to grant the motion to vacate the judgment.

\section{d. Equitable Remedies}

\footnotetext{
${ }^{123}$ See generally, John T. Kolinski, Fraud on the Court as a Basis for Dismissal with Prejudice or Default, 71 FEB. FLA, B. J. 16 (2004)

${ }^{124}$ Songer, 776 N.E.2d at 356.

125 United States v Buck, 281 F.3d 1336, 1341 (10 ${ }^{\text {th }}$ Cir. 2002).; Songer 776 N.E.2d at at 356.

${ }^{126}$ Buck, 281 F.3d at 1341; Songer 776 N.E.2d at 356.

${ }^{127}$ Buck, 281 F.3d at 1342; Stonger 776 N.E.2d at 357.
} 
Foreclosure is an action in equity. ${ }^{128}$ Equitable remedies such as the quiet title action previously discussed are the best means for homeowners seeking relief from a zombie mortgage. Inherent in any equitable claim is the longstanding principal that a person seeking equity must come to the court with clean hands. ${ }^{129}$ The doctrine of unclean hands applies both the lender filing the foreclosure and to the homeowner defending it. "Clean hands" can be a tricky doctrine for a homeowner who admits to having defaulted on the loan. ${ }^{130}$ In most cases, he will be asking the court to determine who, between the debtor and the creditor, has "cleaner hands."

The doctrine of promissory estoppel provides one option for resolving zombie and stalled mortgages, especially if the goal is to force the lender to complete the foreclosure. ${ }^{131}$ Restatement (Second) of Contracts §90 defines promissory estoppel as follows:

A promise which the promisor should reasonably expect to induce action or forbearance on the part of the promisee or a third person and which does induce such action or forbearance is binding if injustice can be avoided only by enforcement of the promise. The remedy granted for breach may be limited as justice requires. ${ }^{132}$

In nearly every stalled, abandoned or zombie mortgage, the homeowners have been misled into believe the home had been foreclosed and they were required to vacate. Kathleen, for example, was induced to move from her home by the lender's promise of a deed in lieu of foreclosure. The homeowner in Kretschmer

\footnotetext{
${ }^{128}$ Equitable Nature of Foreclosure Requires Prior Loss Mitigation, NAT. CONSUMER LAW CENTER , available at https: library.nclc.org/forcl/051303; see generally Steven W. Bender, Equity in Times of Mortgage Crisis, 48 REAL PROP. TR. \& EsT. L.J. 543 (2014).

${ }^{129}$ T. Leigh Anenson, Beyond Chafee: A Process-Based Theory of Unclean Hands, 47 AM. BUS.L.J. 509,515 (2010)

${ }^{130}$ Wolff, 997 F.Supp at 978 (holding that an equitable action by a homeowner could not stand because they were in default of the mortgage); but see Wells Fargo Bank, N.A. v. Hughes, 27 Misc. 3d 628, 634 (Supreme Ct New York 2010) (finding that a lender could not request the equitable remedy on foreclosure because they had unclean hands in the loan modification process).

${ }^{131}$ Marco Jimenez, The Many faces of Promissory Estoppel: An Empirical Analysis Under Restatement (Second) of Contracts, 57 UCLA LAW REV. 669, 690 (2010) (finding that "promissory estoppel cases decided under the Restatement (Second) of Contracts are successful about 53 percent of the time.”)

132 Restatement (Second) Contracts $\$ 90(1981)$
} 
was misled by the creditor's attorney who induced her not to file an answer to the foreclosure complaint because a short sale would be forthcoming. ${ }^{133}$ The Kretschmer court held that evidence that a homeowner relied on the creditor's promise of settlement and failed to take the action necessary to avoid a default was a sufficient reason to set aside the foreclosure. ${ }^{134}$ The Court set aside the default judgment. ${ }^{135}$

Defaults are generally disfavored by courts. Therefore, homeowners should be warned. It may be far easier to get a court to set aside a default judgment than it will be to require a lender to take affirmative action, such as ordering it to sell the property. Still, the doctrine remains the same. If the homeowner relied on the promise to his detriment, a remedy should be available.

The proper remedy for promissory estoppel has been debated for many years. One theory holds that the remedy should only compensate the aggrieved party for the damages caused by the reliance. ${ }^{136}$ Therefore, a homeowner, who moved from the home should perhaps only be compensated for the damages to the home as a result of that reliance. The opposing theory holds that the proper damages is the same as any other contract, the expected result had the contract been performed. ${ }^{137}$ This is a bit harder to conceptualize in this situation. Presumably, that damage would be to put the homeowner in the same position as if the foreclosure had been completed and the home sold. In a recent study,

\footnotetext{
${ }^{133}$ Kretschmer v. Bank of America, 15 N.E.3d. 595, 600 (Ind. App. 2014)

${ }^{134}$ Kretschmer v. Bank of America, 15 N.E.3d 595, 600-01 (Ind. App. 2014); See also, Akar v. Fed. At. Mortg. Ass'n, 845 F. Supp 2d 381 (D. Mass 2012);

${ }^{135}$ Kretschmer v. Bank of America, 15 N.E.3d 595, 600-01 (Ind. App. 2014); Akar v. Fed. At. Mortg. Ass’n, 845 F. Supp 2d 381 (D. Mass 2012);

136 Jimenez, supra note 131 at 679, 684-86.

${ }^{137}$ Id. at $680-81$.
} 
Professor Jimenez has documented that courts currently seem to favor the later of these two theories. ${ }^{138}$ The facts of a zombie mortgage are so unusual for courts, however, makes it is hard to predict how damages will be determined in these cases.

In any case, no discussion of damages is complete without a discussion of the mitigation of damages. This has only recently become an issue in these cases. Once a foreclosure is set aside, there will be a period of time when no payments are accepted, but interest continues to accruing on the loan. The value of the collateral will surely have declined, especially if the property has been abandoned. All of these extra costs to the homeowner or losses to the lender, depending on your perspectives, are directly attributable to the lender's act of starting and then abandoning a foreclosure action. When and if a lender eventually comes back to a homeowner and demands payment or files a subsequent foreclosure action or both, the judgment owed by the homeowner will be much larger than previously.

In Park Tre Investment v. Anderson ${ }^{139}$ the lender obtained a foreclosure judgment of $\$ 22,644.22$. The judgment was set aside and refiled the same month. ${ }^{140}$ This second action required a second filing fee, more interest, more attorney's fees and an additional fee for service. The second judgment, granted 2 months later, was more than $\$ 9,000$ larger than the first. Nothing the homeowner did caused the motion to be set aside and then re-filed. In fact, he was deceased. Yet, the foreclosure judgment has grown by over $\$ 9,000$. Clearly, the lender sees no reason to mitigate its damages. Courts sitting in equity can fashion remedies as justice provides. A court's equitable powers must balance this imbalance and require such mitigation.

\footnotetext{
${ }^{138}$ Id. at 708.

139 71-C01-1010-MF-000600; see chart four, infra p.24.

140 71-C01-1010-MF-000600
} 


\section{e. Abandonment}

One of the most difficult issues facing homeowners is the fact that they are left with a mortgage on the property and a lender who will neither accept payment nor foreclose on the property. If the situation persists long enough, a homeowner may be able to successfully claim a laches defense to a subsequent foreclosure. ${ }^{141}$ This, however, would require a homeowner to wait years before resolving her situation. Most people cannot endure the stress of that alternative.

A novel approach is to ask the court to find that the lender has abandoned the mortgage. Common law holds that you cannot abandon real property. ${ }^{142}$ A mortgage, however, is not real property. Certain rights relating to property can be abandoned. ${ }^{143}$ However, in such cases, the owner is permitted to abandon the benefit, but not the burden of the property. ${ }^{144}$ Interestingly, what zombie mortgage have shown is that courts are willing to allow mortgage lenders to walk away from all the burden of ownership, while retaining all the benefit. They have it backwards.

Abandonment has traditionally been defined as “intentionally and voluntarily relinquishes all right, title, and interest” in the property. ${ }^{145}$ Typically, the intent to abandon is clear. The physical object is simply left somewhere by its owner. ${ }^{146}$ Abandoning a nontangible piece of property, such as a mortgage, is more complicated. Intent can, however, be

\footnotetext{
${ }^{141}$ See, i.e. Insight Assets v. Farias, 321 P.3d. 1021, 1025 (Utah 2013)(“doctrine of laches may apply in equity, whether or not an applicable statute of limitations has been satisfied.”)

${ }^{142}$ Pocono Sprimgs Civic Ass'n v. Mackenzie, 667 A.2d 233, 235-36 (PA. super Ct. 1995), see Eduardo M.

Penalver, The Illusory Right to Abandon, 109 MicH. L. REv. 191, 201 (2010)note 142., Strahilevitz, supra note 53 at 399.

${ }^{143}$ Penalver, supra note 142 at 200-01. Property scholars debate whether this is truly "abandonment" or something different, such as forfeiture. While important on a theoretical level, the result for homeowner or the community attempting to deal with the abandoned property, the result would be the same. The security interest blocking the sale or demolition of the property would no longer be in place. Id. See also, Strahilevitz, suprai note 53.

${ }^{144}$ Penalver, supra note 142 at 200-01.

${ }^{145}$ Penalver, supra note 142 at 196 (quoting John G. Spankling, UNDERSTANDING PROPERTY LAW WAYS $\S$ 4.03[B][1\} (2d. ed. 2007)).

${ }^{146}$ Id. at 196-97.
} 
demonstrated by actions of a party. ${ }^{147}$ Kathleen's case is a good example of how this intent might manifests itself. The lender first promised to accept a deed in lieu and then failed to follow-through, indicating it had no interest in owning the property. It then foreclosed, but failed to secure or sell the property for a period of years. Again, this signals its intent not to enforce the mortgage. Finally, it asks the court to set aside the judgment because it had no interest in selling the property. Each of these acts demonstrated an affirmative acts to abandon its right to the mortgage.

One of the justification for not allowing the abandonment of real property is that it shifts the burden of that ownership to another party without their consent. In effect, it puts the burden of ownership on an unsuspecting and unwilling party. However, a mortgage is a narrow interest in the land. Professor Eduardo Penalver has suggested that "the abandonment of such narrowly drawn land interests does not seem to generate much by way of harmful consequences for third parties." ${ }^{148}$ In fact, it is because the law has not deemed the zombie mortgage abandoned that it has become a "zombie." The zombie has harmed the home owners and entire communities. It has prevented the free alienation of the property that is subject to the mortgage. Scholars have argued that until and unless someone else is willing to take possession of that property, it cannot be abandoned. ${ }^{149}$ Ironically, in the case of a zombie loan there homeowners and communities willing to accept the responsibility of the property, but are prevented because the lender's mortgage. The lender is receiving the benefit of the mortgage, but discharging all the responsibility to others. By far the best and most efficient means to clean up the zombie loans that have plagues the country since the beginning of this crisis is to consider the mortgages on

\footnotetext{
${ }^{147} \mathrm{Id}$.

148 Id. at 212.

${ }^{149} \mathrm{Id}$. at 203.
} 
those properties abandoned. Homeowners and communities can then more easily move in to deal with the related, abandoned properties.

\section{CONCLUSION}

The securitization of the mortgage loans has changed how lenders respond in a time of mortgage crisis. As a result, numerous homeowners have found themselves in the clutches of a zombie loan, a loan that is neither living nor dead. Current law and policy has struggled with how to deal with this new crisis. It is clear that both need to modernize in response.

Policymakers need to acknowledge the changing landscape. Homeowners have the right to know who owns their loan, how much is owed on that debt and who to contact when that debt is in default. This right should continue beyond charge-off until and unless it is completely dead. On a practical level, this means notifying consumers when a debt is sold and to whom.

The judiciary needs to exercise its equitable powers to curb the abuse. These powers include the ability to hold lenders accountable when they misrepresent facts to the homeowner and the courts. A lender who consistently fails to exercise its right to enforce its lien should be deemed to have abandoned it. The unencumbered property can then return to the world of commerce to be sold, repaired or destroyed, if necessary.

Finally, communities need to work with homeowners to achieve these ends. Most homeowners who become aware of a zombie loan do so as a result of a code enforcement proceeding. Municipalities should work with these homeowners, most of whom relied in good faith on information from their lender before they moved, to hold the proper party accountable for the plague of zombie mortgages left in the wake of this last foreclosure crisis. The lenders and their servicers created these zombies. They, and not homeowners and communities, should bear the burden of exterminating them. 
